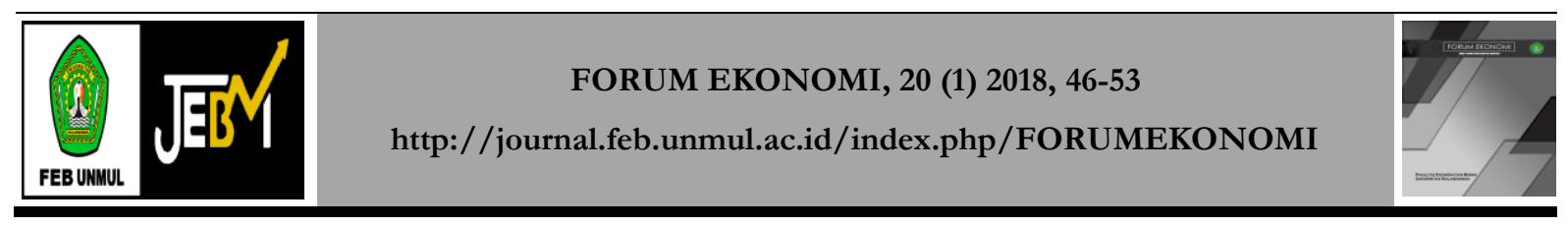

Pengaruh harga dan pendapatan perkapita terhadap permintaan udang windu

\author{
Taufiq $^{1}$, Zamruddin Hasid ${ }^{2}$, Akhmad Noor ${ }^{3}$ \\ Fakultas Ekonomi dan Bisnis Universitas Mulawarman, Samarinda \\ ${ }^{1}$ Email: fiqnata@gmail.com \\ ${ }^{2}$ Email: zamriddin.hasid@feb.unmul.ac.id \\ ${ }^{3}$ Email: akhmad.noor@feb.unmul.ac.id
}

\begin{abstract}
Abstrak
Pembahasan penelitian ini adalah untuk menganalisis pengaruh harga dan pendapatan per kapita terhadap udang windu di Kutai Kartanegara 2005-2015. Penelitian ini menggunakan pengujian hipotesis dengan menggunakan analisis regresi linier berganda (Cobb-douglas) berdasarkan data sekunder yang diolah di Dinas Kelautan dan Perikanan Kutai Kartanegara dan Biro Pusat Statistik Kota Samarinda. Hasil analisis menunjukkan bahwa harga efek negatif dan signifikan udang windu, dan pendapatan positif per kapita berpengaruh dan signifikan terhadap permintaan udang windu di Kutai Kartanegara 2005 - 2015.

Kata Kunci: Harga udang windu; pendapatan per kapita; permintaan shampo harimau

\section{The influence of price and income per capita on demand of tiger shrimp}

Abstract

The perpouse of this research is to analiysis the effect of price and income per capita to tiger shrimp in Kutai Kartanegara 2005-2015. The study used hypothesis testing using multiple linier regression analysis (Cobb-douglas) on the basis of secondary data processed in the Department of marine dan fisheries Kutai Kartanegara and the Central Bureau of statistics City of Samarinda. The results of the analysis showed that the price of a negative and significant effect of tiger shrimp, and influential positive per capita income and the significant against the demand for tiger shrimp in Kutai Kartanegara 2005 - 2015.
\end{abstract}

Keywords: Price of tiger shrimp; per capita income; demand tiger shrip 


\section{PENDAHULUAN}

Pembangunan sektor perikanan merupaka sektor yang memberikan kontribusi terhadap perekonomian di Kalimantan timur. Khususnya di kabupaten Kutai Kartanegara yang merupakan kabupaten yang memiliki potensi sumber daya perikanan terbesar di Kalimantan timur, ditinjau dari segi aspek ekologis, keadaan alam, sumber air dan iklim di Kutai Kartanegara sangat menunjang pada usaha budidaya perikanan. Udang merupakan hasil budidaya yang banyak dicari oleh masyarakat karna memiliki rasa yang lezat dan gizi yang tinggi. selain itu kuliner udang menjadi banyak pilihan masyarakat sehingga permintaan dari kebutuhan udang di Indonesia sendiri terus meningkat. udang sendri terdiri dari beberapa jenis, dimana dari masing- masing jenis udang tersebut memiliki rasa serta harga yang berbeda-beda. tentunyasemakin baik kualitas dari udang maka semakin mahal harga jualnya. Udang windu merupakan komoditi unggulan di Negara kita, sampai saat ini udang windu terus menjadi idola bagi para pengusaha tambak karna tingginya permintaan pasar pada jenis udang ini. hal ini lah yang membuat banyak petani yang tidak kapok untuk budidaya udang windu meski bisnis udang ini sering turun naik atau tidak stabil. Produk perikanan sebagai bahan makanan dibutuhkan karna masyrakat modern menyadari bahwa kesehatan tubuh sangatlah penting. Kepedulian masyarakat terhadap kesehatan berpengaruh terhadap pola konsumsi, khususnya konsumsi dari jenis ikan yang banyak disarankan oleh ahli gizi. Perkembangan usaha budidaya perikanan saat ini, terus di upayakan untuk dikembangkan seiring dengan menurut direktorat jendral perikanan budidaya (DJPB) Kementrian Kelautan dan Perikanan (KKP) yang menyatakan bahwa permintaan terhadap jenis ikan dari tahun ke tahun menunjukkan kecendrungan mengalami peningkatan sebagai akibat dari meningkatnya jumlah penduduk dan kualitas hidup yang diikuti dengan perubahan pola konsumsi masyarakat. Pada dasarnya permintaan suatu barang mengikuti hukum permintaan yang menyatakan bahwa apabila harga suatu barang naik, maka jumlah yang diminta akan turun sedangkan apabila harga suatu barang turun maka permintaan akan naik dengan catatan apabila hal-hal lain tetap. Artinya bahwa tingkat harga mempengaruhi jumlah permintaan. Namun pada kenyataannya permintaan suatu barang tidak hanya dipengaruhi oleh harga barang itu sendiri, tetapi dapat pula di pengaruhi oleh harga barang lain yang biasa menjadi subtitusi atau komplementer barang tersebut yang di pengaruhi oleh kualitas barang dan rancang bangun, saluran distribusi dan penjualan, pendapatan masyarakat dan selera (preferensi konsumen). Namun dalam penelitian ini peneliti akan berkonsentrasi pada permintaan berdasarkan harga dan pendapatan perkapita terhadap permintaan udang windu di Kabupaten Kutai Kartanegara.

\section{Kajian Pustaka \\ Teori Produksi}

Kata produksi berasal dari kata dalam bahasa inggris "production" yang berarti membuat atau menghasilkan suatu barang dari bahan lain. Secara mudah arti produksi dapat di artikan sebagai suatu kegiatan untuk menghasilkan sesuatu dari yang tidak ada menjadi ada. Kebutuhan manusia pada dasarnya sangat besar jumlahnya dan jenisnya, tidak ada seorangpun yang dapat meramalkan, sehinggga dapat dikatakan kebutuhan manusia tidak terbatas baik dalam jumlah maupun jenisnya. Untuk memuaskan kebutuhannya, manusia sangat membutuhkan barang dan jasa. Dalam usaha untuk memenuhi kebutuhannya itu, manusia dihadapkan pada kenyataan bahwa barang-barang dan jasa-jasa itu terbatas jumlahnya. Hal ini dikarenakan jumlah barang pemuas kebutuhan yang dikonsumsi tidak sebanding dengan jumlah barang dan jasa yang tersedia dan yang di produksi, dengan kata lain kebutuhan manusia yang sangat banyak dan yang tidak terbatas akan konsumsi barang pemuas kebutuhan, sedangkan faktor-faktor produksi yang digunakan untuk menciptakan barang pemuas kebutuhan jumlahnya sangat terbatas sehingga mengakibatkan kurang dan sedikitnya jumlah barang pemuas kebutuhan dengan yang dibubuhkan manusia.

\section{Teori Permintaan}

Dalam ilmu ekonomi, istilah permintaan (demand) mempunyai arti adanya suatu hubungan tertentu antara jumlah suatu barang dan jumlah suatu barang yang mau dibeli orang dan harga barang tersebut. hal-hal yang berhubungan dengan permintaan adalah pertama adalah kemauan dan kemampuan untuk membeli suatu barang. kemauan dan kemampuan saja tidak cukup untuk membeli suatu barang, harus disertai dengan keinginan dan kemampuan untuk membeli barang tersebut dan didukung uang yang cukup untuk membayar harga barang tersebut. 
Jumlah barang yang mau di beli adalah jumlah yang diinginkan. Jumlah barang yang mau di beli harus dinyatakan dalam jangka waktu tertentu (per tahun, per bulan, per hari). ceteris paribus yang berarti banyaknya jumlah barang/jasa yang mau dibeli oleh masyarakat selama periode tertentu yang dipengaruhi oleh faktor harga itu sendri, harga barang lain, pendapatan, dan lainnya di anggap konstan.

\section{Kurva Permintaan}

Jika dimisalkan permintaan seseorang hanya dipengaruhi oleh harga barang itu sendiri, maka setiap perubahan harga barang itu sendiri, maka setiap perubahan harga barang tersebut akan mempengaruhi keputusan konsumen untuk menentukan berapa jumlah yang akan diminatinya, dalam hukum permintaan mengatakan bahwa apabila harga suatu barang naik maka jumlah barang yang diminta akan turun, apabila harga suatu barang turun maka barang diminta akan naik.

\section{Elastisitas Permintaan}

Elastisiitas permintaan adalah suatu ukuran kualitatif untuk menghitung berapa besar perubahan harga yang terjadi karna perubahan jumlah dan sebaliknya.

Manfaat dari memahami elastisitas: Dipakai oleh perusahaan untuk mengetahui keadaan pasar, apakah perlu menaikkan produksi untuk menaikkan hasil penjualan atau kenaikan produksi menurunkan hasil penjualan. Untuk pemerintah, dapat dipakai untuk mengetahui dan meramalkan kebijakan pemerintah. Elastisitas permintaan dipengaruhi oleh beberapa Faktor diantaranya adalah:

Banyaknya barang pengganti.

Di dalam suatu perekonomian terdapat banyak barang yang dapat digantikan dengan barangbarang lain yang sejenis, tetapi adapula yang sukar dicari pengantinya. sekiranya barang mempunyai banyak barang pengganti, maka permintaan cendrung bersifat elastis. Pada waktu harga naik pembeli akan enggan membeli barang tersebut dan menggantinya dengan barang lain yang sejenis yang harganya tidak mengalami perubahan. Permintaan atas barang-barang yang tidak memiliki barang pengganti bersifat tidak elastis, karna bila harga naik pembeli tetap harus membeli barang tersebut. dan apabila harganya turun permintaan nya tidak banyak bertambah.

Persentase pendapatan yang harus dikeluarkan untuk memperoleh suatu barang.

Jika barang yang dibeli murah, maka elastisitas permintaannya tidak elastis. Tapi apabil barang yang dibeli memerlukan sebagian besar jumlah pendapatan seseorang, maka permintaan elastis.

Jangka waktu, jangka waktu didalam masa permintaan atas suatu barang diamati juga mempunya pengaruh terhadap elastisitas, makin lama jangka waktu dimana permintaan itu dianalisis makin elastis karna perubahan-perubahan yang baru terjadi dalam pasar belum diketahui oleh pembeli. Elastisitas adalah ukuran persentase perubahan suatu variabel yang disebabkan satu persen perubahan variabel lainnya, elastisitas permintaan juga merupakan ukuran kuantitatif yang menunjukkan seberapa besar pengaruh perubahan harga maupun faktor lainnya terhadap perubahan permintaan dari suatu komoditas. elastisitas dibutuhkan untuk mengetahui sejauh mana respon terhadap perubhan kuantitas yang diminata akibat perubahan faktor-faktor yang mempengaruhinya. koefisien elastisitas itu sendiri dapat didefinisikan sebagai persentase perubahan dalam variabel yang tak bebas (dependen variabel) dibagi dengan perubahan dalam variabel bebas (independen variabel).

\section{Pendapatan}

Didalam kehidupan ekonomi dewasa ini, baik tingkat regional, maupun nasional bahkaninternasional masalah pendapatan menjadi perbincangan yang serius dari berbagai pihak, karena pendapatan merupakan salah satu indikator ekonomi untuk mengukur kemakmuran dan keadilan. Dibidang ekonomi suatu masyarakat. pendapatan seseorang juga dapat didefinisikan sebagai banyaknya penerimaan yang dinilai dengan satuan uang yang dapat dihasilkan seseorang atau suatu bangsa dalam periode tertentu. "Pendapatan (revenue) dapat di artikan sebagai total penerimaan yang diperoleh pada periode tertentu". Dengan demikian dapat di simpulkan bahwa pendapatan adalah sebagai jumlah penghasilan yang diterima oleh para anggota masyarakat untuk jangka waktu tertentu sebagai balas jasa atau faktor-faktor produksi yang telah disumbangkan. Tingkat pendaptan merupakan suatu kriteria maju tidaknya suatu daerah. Bila pendapatan suatu daerah relative rendah, dapat dikatakan bahwa kemajuan dan kesejahtraan terseebut akan rndah pula. Kelebihan dari kunsumsi maka akan disimpan pada bank yang tujuannya adalah untuk berjaga-jaga apabila baik kemajuan bidang pendidikan, produksi dan sebagainya juga mempengaruhi tingkat tabungan masyarakat. Demikian pula hanya bila pendaptan 
masyarakat suatu daerah relative tingggi, maka tingkat kesejahtraan dan kemajuan daerah tersebut tinggi pula.

\section{Usaha Perikanan}

Usaha perikanan itu sendiri mencakup setiap usaha perseorangan ataupun badan hukum dalam menangkap ataupun membudidayakan ikan demi menciptakan nilai tambah ekonomi bagi para pelaku usaha. Perikanan apabila di kelola dengan baik dan benar bisa menghasilkan keuntungan financial yang tidak sedikit, karna seperti kita ketahui sebagian besar bumi kita ini terdiri dari $70 \%$ air dan 30\% daratan. Melakukan pengoptimalisasian dari fakta tersebut jelas akan memberikan keuntungan cukup besar bagi manusia. Dalam dunia usaha perikanan dikenal 3 bidang usaha, Diantaranya adalah sebagai berikut:

Usaha perikanan budidaya/ aquaqultur, yaitu suatu kegiatan usaha yang bertujuan untuk memproduksi ikan dalam suatu wadah pemeliharaan yang dikontrol dan berorientasi kepada suatu keuntungan. Misalnya budidaya ikan lele, ikan patin, ikan nila, udang windu dan lain sebagainya. Usaha ini biasa dilakukan dalam bentuk tambak-tambak, kolam- kolam, empang-empang yang diatur sedemikian rupa sehingga memiliki kondisi sempurna untuk mengembangkan sumber daya yang dibiakkan. Istilah budidaya perairan (aquaqultur).

Usaha perikanan pengolahan, yaitu suatu kegiatan usaha dengan tujuan untuk meningkatkan nilai tambah yang dimiliki oleh suatu produk perikanan. Selain itu, usaha perikanan pengolahan ini juga bertujuan sebagai pendekatan produk perikanan terhadap pasar dengan harapan agar dapat diterima oleh konsumen secara luas dan menyeluruh. misalnya saja dalam pembuatan kerupuk udang, bakso ikan dan juga sosis kan dan usaha- usaha jenis lainnya.

Usaha tangkap ikan, usaha satu ini adalah suatu kegiatan usaha yang terfokus dalam produksi ikan dengan jalan menangkap ikan yang berasal dari perairan darat maupun perairan laut. Misalnya saja usaha penangkapan ikan tuna, ikan sarden, ikan tongkol, ikan layang dan jenis ikan lainnya. usaha ini dilakukan dengan kapal-kapal yang dilengkapi peralatan khusus untuk menangkap hasil laut yang ditujukan guna mendapatkan hasil yang optimal, sempat metode ini mendapat banyak sorotan karena tidak sedikit usaha ini menyebabkan kerusakan habitat alam bawah air karena penangkapan dengan metode yang tidak bertanggung jawab seperti bom ikan, dan juga pukat harimau. Namun sekarang sudah di pertegas dengan undang-undang.

\section{METODE}

\section{Alat Analisis}

Pengujian hipotesis dan memperoleh gambaran tentang permintaan udang di Kabupaten Kutai Kartanegara, maka data dianalisis secara kualitatif dan kuantitatif. Pada pengujian hipotesis ini menggunakan 3 variabel, adapun variabel dalam penelitian ini yaitu harga udang itu sendiri, pendapatan perkapita, dan permintaan udang windu di Kabupaten Kutai Kartanegara.Analisis data yang di peroleh yaitu data Sekunder dimana data diperoleh dari instansi pemerintahan yaitu kantor Dinas Kelautan dan Perikanan Kabupaten Kutai Kaetanegara dan Badan Pusat Statistik Kota Samarinda, serta berbagai teori yang terpercaya melalui penelitian kepustakaan didalam penelitian ini penulis mencoba menganalisis permintaan akan permintaan udang yang dipengaruhi oleh tingkat harga udang itu sendiri, dan pendapatan perkapita. Model fungsi permintaan yang digunakan adalah Model Fungsi Cobb- Douglas dengan formulasi sebagai berikut:

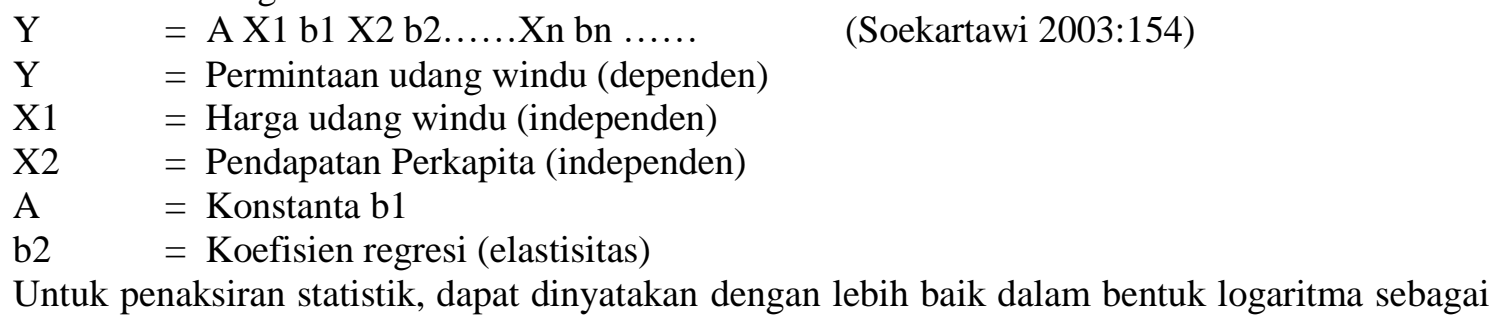
berikut:

$\log \mathrm{Y}=\log \mathrm{A}+\mathrm{b} 1 \log \mathrm{X} 1+\mathrm{b} 2 \log \mathrm{X} 2$

Maka Diperoleh persamaannya sebagai berikut:

$\mathrm{Y}=\mathrm{b} 0+\mathrm{b} 1 \mathrm{X} 1+\mathrm{b} 2 \mathrm{X} 2$ 
untuk mendapatkan nilai b0, b1, b2, dapat diselesaikan dengan menggunakan aljabar matriks sebagai berikut:

$\Sigma \mathrm{Y}=\mathrm{nb} 0+\mathrm{b} 1 \Sigma \mathrm{X} 1+\mathrm{b} 2 \Sigma \mathrm{X} 2 \Sigma \mathrm{YX} 1=\mathrm{b} 0 \Sigma \mathrm{X} 1+\mathrm{b} 1 \Sigma \mathrm{X} 12+\mathrm{b} 2 \mathrm{X} 1 \mathrm{X} 2 \Sigma \mathrm{YX} 2=\mathrm{b} 0 \Sigma 2+\mathrm{b} 1$

$\Sigma \mathrm{X} 1 \mathrm{X} 2+\mathrm{b} 2 \Sigma \mathrm{X} 2 \mathrm{n} \Sigma \mathrm{X} 1 \Sigma \mathrm{X} 2 \mathrm{~b} 0 \Sigma \mathrm{Y} \Sigma \mathrm{X} 1 \Sigma \mathrm{X} 12 \Sigma \mathrm{X} 1 \mathrm{X} 2 \mathrm{~b} 1=\Sigma \mathrm{X} 1 \mathrm{Y} \Sigma \mathrm{X} 2 \Sigma \mathrm{X} 1 \mathrm{X} 2 \Sigma \mathrm{X} 1 \mathrm{X} 22 \mathrm{~b} 2$

$\Sigma \mathrm{X} 2 \mathrm{Y}$ A1 det $\mathrm{A} 1 \mathrm{~b} 0==\mathrm{A} \operatorname{det} \mathrm{A}(\Sigma \mathrm{x} 1 \mathrm{y})(\Sigma \mathrm{x} 22)-(\Sigma \mathrm{x} 2 \mathrm{y})(\Sigma \mathrm{x} 1 \mathrm{x} 2) \mathrm{b} 1=(\Sigma \mathrm{x} 12)(\mathrm{x} 22)-(\Sigma \mathrm{x} 1 \mathrm{x} 2)$

$(\Sigma \mathrm{x} 2 \mathrm{y})(\Sigma \mathrm{x} 12)-(\Sigma \mathrm{x} 2 \mathrm{y})(\Sigma \mathrm{x} 1 \mathrm{x} 2) \mathrm{b} 2=(\Sigma \mathrm{x} 12)(\mathrm{x} 22)-(\Sigma \mathrm{x} 1 \mathrm{x} 2)$

Pengujian hipotesis penulis menggunakan uji Asumsi kelasik (Autokorelasi, Multikolinieritas, Heterokedastisitas) dan uji R, uji F (uji serentak) uji t (uji parsial), uji R2 untuk mengetahui besaran pengaruh antara variabel bebas dengan variabel tidak bebas.

\title{
Asumsi Klasik
}

Uji Autokorelasi bertujuan menguji apakah dalam model regresi linier korelasi antara kesalahan pengganggu pada periode $t$ dengan kesalahan pengganggu pada periode $\mathrm{t}-1$ (sebelumnya). Jika terjadi korelasi, maka dinamakan ada problem autokorelasi, ada tidaknya gejala autokorelasi dideteksi menggunakan uji Durbin-Watson (DW-test). Uji autokorelasi dengan melakukan Durbin-Watson test dengan berbagai macam syarat dimana tidak terjadi autokorelasi bila: Jika Hipotesis nol $0<\mathrm{dw}<\mathrm{Dl}$ Tidak terjadi autokorelasi positif $\mathrm{dL}<\mathrm{dw}<\mathrm{Du}$ Tidak ada autokorelasi positif $4-\mathrm{dL}<\mathrm{dw}<4$ Tidak ada autokorelasi negative $4-\mathrm{dL}<\mathrm{dw}<4 \ldots \mathrm{dL}$ Tidak ada positif atau negative autokorelasi $\mathrm{dL}<\mathrm{dw}<4-\mathrm{dU}$ Tidak ada positif atau negative autokorelasi

\section{Multikolinieritas}

Ada banyak cara untuk menentukan apakah suatu model memiliki gejala multikolinieritas, dengan 2 cara yaitu dengan melihat nilai VIF dan nilai Tolerance.

VIF. Cara ini sangat mudah, hanya melihat apakah nilai VIF untuk masing - masing variabel lebih besar dari 10 atau tidak. bila nilai VIF lebih besar dari 10 maka diindikasikan model tersebut memiliki gejala multikolinieritas, sedangkan apabila nilai VIF lebih kecil dari 10 maka dapat dikatakan tidak memiliki gejala multikolinieritas.

Tolerance. Cara kedua adalah dengan melihat nilai tolerance masing-masing varibel lebih besar dari 0,10 atau tidak. terjadi multikolinieritas apabila nilai tolerance lebih kecil atau sama dengan 0,10. Sedangkan apabila nilai tolerance lebih besar dari 0,10 maka dapat dikatakan tidak terjadi multikolinieritas.

\section{Uji Heteroskedastisitas}

Uji Heterokedastisitas bertujuan untuk menguji apakah dalam model regresi memiliki variance residual tidak sama dari satu pengamatan ke pengamatan yang lain. Ada beberapa cara yang dapat dilakukan untuk melakukan uji heterokedastisitas, yaitu dengan menggunakan uji grafik Plot, uji Park, uji Glejser, dan uji White. pengujian dalam penelitian ini menggunakan Grafik Plot antara nilai prediksi variabel independen yaitu ZPRED dengan residualnya SRESID. Jika terdapat pola tertentu pada grafik scatterplot, seperti titik-titik yang membentuk pola yang teratur, maka dapat disimpulkan bahwa terjadi heterokedastisitas sedangkan apabila tidak ada pola yang jelas, serta titik-titik menyebar diatas dan dibawah angka 0 (nol) pada sumbu Y. maka dapat disimpulkan tidak terjadi heterokedastisitas. (Ghozali,2011: 139-143)

\section{Uji R}

Uji R digunakan untuk mengetahui kuat lemahnya hubungan antaravaribel independen secara bersamaan terhadap varibel dependen. Semakin besar nilai R, maka semakin kuat hubungan variabel independen secara bersamaan terhadap variabel dependen. Apabila dalam memberikan penafsiran terhadap koefisien korelasi yang ditemukan tersebut kuat atau tidaknya dapat dilihat dari interprestasi koefisien korelasi sebagai berikut:

\author{
Interval Koefisien dan Tingkat Hubungan Interval koefisien Tingkat hubungan \\ $0,00-0,199$ \\ $0,2-0,399$ \\ $0,4-0,599$ \\ $0,6-0,799$ \\ $0,8-1$ \\ Korelasi Sangat Rendah
}


Korelasi Rendah Korelasi Sedang Korelasi Kuat Korelasi Sangat Kuat

Perhitungan Koefisien Determinasi (R2)

Koefisien determinasi digunakan untuk mengetahui besarnya persentase variasi yang dapat dijelaskan. Semakin besar nilai R2, maka semakin tepat model regresi yang dipakai sebagai alat peramalan, karena total variasi, dapat menjelaskan variabel tidak bebas. koefisien determinasi dapat dihitung dengan menggunakan rumus berikut ini: $\mathrm{R} 2=\sqrt{\mathrm{b}} 1 \Sigma \mathrm{X} 1 \mathrm{Y}+\mathrm{b} 2 \Sigma \mathrm{X} 2 \mathrm{Y} \Sigma \mathrm{Y} 2$

\section{Uji F (uji serentak)}

Pengujian secara serentak adalah untuk mengetahui apakah secara serentak koefisien regresi variabel bebas mempunyai pengaruh atau tidak terhadap variabel tidak bebas.

Ho : $\mathrm{b} 1=\mathrm{b} 2=0$ artinya tidak terdapat pengaruh yang nyata $\mathrm{b} 1$ terhadap permintaan udang.

$\mathrm{Ha}: \mathrm{b} 1 \neq \mathrm{b} 2 \neq 0$ Minimal satu parameter estimator $\neq 0$ artinya terdapat pengaruh yang nyata b1 terhadap permintaan udang. Pembuktian ini dilakukan dengan mengamati $\mathrm{F}$ (hitung) pada nilai alpha tertentu yaitu 0,05 atau $5 \%$. Apabila nilai $\mathrm{F}$ (hitung) lebih besar atau sama dengan $\mathrm{F}$ table, atau signifikan $<0,05$ maka HO ditolak, namun jika sebaliknya maka Ha ditolak.

Untuk mengetahui pengaruh seluruh variabel digunakan pengujian data dengan menggunakan uji F sebagai berikut (makridakis, 2002: 286):

$\mathrm{F}=\mathrm{R} 2 /(\mathrm{k}-1)(1-\mathrm{R} 2)(\mathrm{n}-\mathrm{k}-1)$

dimana :

R2 $=$ Koefisien Determinasi $\mathrm{k}=$ Jumlah Variabel

$\mathrm{N} \quad=$ Jumlah Sampel

\section{Uji t (Uji parsial)}

Pengujian secara parsial digunakan untuk menguji apakah masingmasing variabel bebas mempunyai pengaruh atau tidak terhadap variabel tidak bebas. $\mathrm{H} 0: \mathrm{b} 1=0$, artinya tidak terdapat pengaruh yang nyata $b 1$ terhadap permintaan udang. Ha: $b 1 \neq 0$, artinya terdapat pengaruh yang nyata b1 terhadap permintaan udang. Pembuktian dilakukan dengan mengamati t hitung pada nilai alpha tertentu, yaitu 0,05 (5\%). Apabila nilai t hitung lebih besar atau sama dengan $t$ table, atau signifikan < 0,05 maka HO ditolak, namun jika sebaliknya Ha ditolak. Untuk mengetahui pengaruh setiap variable digunakan pengujian dengan formula sebagai berikut (Makridakis, 2002: 288): $\mathrm{Bi} \mathrm{t}=\mathrm{Sbi}$

Dimana:

$$
\begin{array}{ll}
\mathrm{t} & =\text { Nilai " } \mathrm{t} \text { " hitung } \\
\mathrm{bi} & =\text { Koefisien Regresi ke } \mathrm{i} \\
\mathrm{Sbi} & =\text { Standar Deviasi ke } \mathrm{i}
\end{array}
$$

Alat analisis dan semua pengujian hipotesis ini perhitungannya menggunakan program komputer statistik SPSS 23. Penggunaan program komputer pada penelitian ini dimaksudkan untuk mempercepat proses perhitungan dan keakuratan hasil perhitungan.

\section{HASIL DAN PEMBAHASAN}

Berdasarkan dari hasil perhitungan koefisien korelasi yang menunjukkan bahwa terdapat hubungan yang sangat kuat antara variabel harga udang dan pendapatan perkapita terhadap permintaan udang windu. Dari nilai perhitungan koefisien korelasi dapat juga dilihat hasil perhitugan koefisien determinasi R2 yang menunjukkan kemampuan antara variabel harga udang dan pendapatan perkapita, menjelaskan permintaan udang windu sebesar $65,6 \%$, adapun sisanya $34,4 \%$ di jelaskan oleh variabel lain yang tidak termaksuk dalam penelitian ini. Berdasarkan pengujian dengan menggunakan uji $\mathrm{F}$ diperoleh hasil bahwa Fhitung 7,639 jika dibandingan dengan Ftabel pada drajat kebebasan Df 1= (k1) atau 3-1=2 dan Df $2=(\mathrm{n}-\mathrm{k})$ atau $11-3=8$, pada tabel didapatkan nilai Ftabel 4,46 , ini menunjukkan bahwa Fhitung 7,639 > Ftabel 4,46 dengan signifikasinya $0,014<\alpha=0,05$ yang berarti secara bersamasama variabel harga udang windu dan variabel. Pendapatan perkapita mempunyai pengaruh yang signifikan terhadappermintaan udang windu di Kabupaten Kutai Kartanegara. Nilai thitung variabel harga udang windu sebesar -2.384. sedangkan nilai ttabel $(\mathrm{Df}=\mathrm{n}-\mathrm{k}-1)$ atau $11-2-1=8$, pada tabel diproleh nilai ttabel 2,306, ini menunjukkan bahwa thitung $-2,384<$ ttabel $-2,306$ dengan signifikannya $0,044<\alpha=0,05$, yang berarti bahwa variabel harga udang mempunyai pengaruh yang signifikan terhadap permintaan udang windu. Nilai thitungvariabel pendapatan perkapita sebesar 3,737 sedangkan nilai ttabel $(\mathrm{Df}=\mathrm{n}-\mathrm{k}-1)$ atau 11-2-1=8, pada tabel diproleh nilai ttabel 2,306, ini menunjukkan bahwa thitung 
$3,737>$ ttabel 2,306 dengan dengan signifikannya $0,006<\alpha=0,05$, yang berarti bahwa variabel pendapatan perkapita mempunyai pengaru yang signifikan terhadap permintaan udang windu. Berdasarkan hasil penelitian variabel independen dimana harga memiliki pengaruh yang signifikan terhadap permintaan udang windu di Kabupaten Kutai Kartanegara. hasil penelitian ini sesuai dengan teori (Wilson,2007:59) Permintaan suatu barang berkaitan dengan jumlah permintaan keatas suatu barang pada tingkat harga tertentu, konsumen dapat menentukan jumlah barang yang dikonsumsi tergantung pada harga barang tersebut. Hal ini sesuai dengan dengan hukum permintaan yang menyatakan bahwa apabila harga suatu barang naik maka permintaan akan barang tersebut akan turun sedangkan apabila harga suatu barang turun maka permintaan akan barang tersebut akan naik (ceteris paribus).

Penelitian ini sejalan dengan penelitian Fadli (2015) mengenai Analisis Permintaan Udang di kabupaten Kutai Kartanegara. Berdasarkan analisis (uji-t) diketahui bahwa variabel harga udang berpengaruh signifikan terhadap permintaan udang dikabupaten kutai kartanegara. Alasan mengapa harga udang windu berpengaruh sigifikan terhadap permintaan udang windu dikarenakan harga udang windu perkilonya relative lebih mahal, namun tidak menutup kemungkinan keinginan seseorang untuk mengkonsumsi udang windu berkurang karna selain sebagai sumber protein asal ikan permintaan akan udang windu juga berasal dari restaurant seafood dan juga dari bidang perhotelan. Berdasarkan pada hasil penelitian variabel independen (pendapatan perkapita) memiliki pengaruh yang signifikan terhadap permintaan udang windu di Kabupaten Kutai Kartanegara, dan terdapat hubungan yang bersifat positif antara pendapatan perkapita dengan permintaan udang windu di kabupaten Kutai Kartanegara. Hasil penelitian ini sesuai dengan teori (Suparmoko,2004: 22), yang menyatakan bahwa faktor utama yang menentukan konsumsi seseorang konsumen akan barang dan jasa adalah tingkat pendapatan konsumen tersebut, tingkat pendapatan berpengaruh secara positif, dalam arti bahwa apabila pendapatan konsumen naik, maka pengeluaran konsumsinya juga akan mengalami kenaikan begitu pula sebaliknya apabila pendapatan konsumen turun maka pengeluaran konsumsinya juga akan menurun. Alasan mengapa pendapatan perkapita berpengaruh signifikan dan terdapat hubungan yang bersifat positif antara pendapatan perkapita dengan permintaan udang windu di Kabupaten Kutai Kartanegara. karna semakin bertambahnya pendapatan masyarakat mereka akan memilih barang yangbernilai lebih dan cendrung memilih jenis udang yang lebih bagus yaitu udang windu. Pertambahan pendapatan perkapita juga memungkinkan konsumen untuk menukar konsumsi mereka dari barang-barang yang kurang baik mutunya ke barang yang lebih baik sehingga meningkatkan permintaan udang windu.

\section{SIMPULAN}

Harga udang windu berpengaruh negatif dan signifikan terhadap permintaan udang windu di Kabupaten Kutai Kartanegara, karna semakin tinggi harga udang windu maka permintaan terhadap udang windu akan mengalami penurunan, begitu juga sebaliknya.

Pendapatan Perkapita berpengaruh positif dan signifikan terhadap permintaan udang windu di Kabupaten Kutai Kartanegara, karna semakin tinggi pendapatan maka semakin tinggi pula tingkat konsumsi seseorang terhadap suatu barang.

\section{DAFTAR PUSTAKA}

Assauri, Sofyan, 2002. Manajemen produksi dan Operasi, Edisi Revisi, Lembaga penerbit Fakultas Ekonomi Universitas Indonesia, Jakarta.

Amirullah, 2002. Perilaku Konsumen, Graha Ilmu, Yogyakarta.

Boediono, 2001. Ekonomi Mikro, Edisi Ketiga, Cetakan Keempat, BPFE Universitas Gajah Mada, Yogyakarta. Ghozali, Imam. 2011. Aplikasi Analisis Multivariate Dengan Program SPSS (edisi kelima), Universitas Diponegoro Semarang.

Herlambang, Tedy, 2002. Ekonomi Manajerial Dan Strategi Bersaing, Edisi Kesatu, PT. Raja Grafindo Persada, Jakarta.

Mulyadi. S, 2005. Ekonomi Kelautan. PT. Raja Grafindo Persada, Jakarta. Makridakis, Spyros, 2002. Metode dan Aplikasi Peramalan, Alih Bahasa Hari Suminto, Airlangga, Jakarta. 
Partadireja, Ace, 2004. Pengantar Ekonomi, BPFE-UGM, Yogyakarta. Sadono, Sukirno, 2004. Makro Ekonomi Teori Pengantar. PT. Raja Grafindo Perkasa, Jakarta. .

Sumarno, 2007. Ekonomi Mikro, Unit Penerbitan dan Percetakan AMP.YKPN. Yogyakarta.

Sudiyono, 2000. Teori Ekonomi Mikro, Perilaku Harga Pasar dan konsumen. Liberty, Yogyakarta.

Sadono, Sukirno, 2005. Pengantar Ekonomi Mikroekonomi, Rajawali Press, Jakarta.

Soekartawi, 2003. Teori Ekonomi Produksi Dengan Pokok Bahasan Analisis Fungsi Cobb-Douglas. PT. Raja Grafindo Persada, Jakarta.

Suparmoko, 2004. Pengantar Ekonomi Makro. Unit Penerbit dan Percetakan AMP. YKPN, Yogyakarta.

Sadono, Sukirno, 2000. Pengantar Teori Ekonomi Mikro, Raja Grafindo Persada, Jakarta.

Sadono, Sukirno, 2002. Pengantar Ekonomi Mikro, LP3ES, Jakarta Samuelson, A Paul, 1997. Pengantar Teori Ekonomi, Erlangga, Jakarta.

Tri Kumalangsih Pracoyo dan Antyo Pracoyo, 2006. Aspek Dasar Ekonomi Mikro, PT. Grasindo, Jakarta.

Wilson, 2007. Teori Ekonomi Mikro, PT. Rafika Aditama. Bandung. 